\title{
Transillumination: shining a light from within
}

\author{
Muhammad Irfan, ${ }^{1}$ Ronan Waldron, ${ }^{2}$ Jarlath Bolger, ${ }^{2}$ Kevin Barry ${ }^{1,3}$
}

${ }^{1}$ Department of Surgery, Mayo General Hospital, Castlebar, Ireland

${ }^{2}$ Mayo General Hospital, Castlebar, Ireland ${ }^{3}$ University Hospital Galway, Galway, Ireland

\section{Correspondence to} Muhammad Irfan, caliber48@hotmail.com

Accepted 28 October 2014

\section{(1) CrossMark}

\section{To cite: Irfan $\mathrm{M}$,} Waldron R, Bolger J, et al. BMJ Case Rep Published online: [please include Day Month Year] doi:10.1136/ bcr-2014-207910

\section{DESCRIPTION}

Thorough examination of a scrotal mass includes transillumination.

By holding a light externally to the scrotum, one can easily determine whether the mass is cystic (light shines through) or solid (light blocked by the mass). At first glance, figure 1 is likely to be interpreted as a transillumination test to confirm the presence of hydrocele. More careful inspection confirms the peripheral location of the examiner's gloved hands and the absence of an external light source. Where is the light source located? This image was observed during limited colonoscopy performed in a 74-year-old man with long-standing left inguinoscrotal hernia and a recent history of altered bowel habits. Colonoscopy was limited to $35 \mathrm{~cm}$ due to the presence of an incarcerated loop of sigmoid colon. The light source is therefore located at the level of the mid-sigmoid colon, which in turn is located within the scrotal component of the hernial sac. There have been 16 cases reported to date in the world literature document-

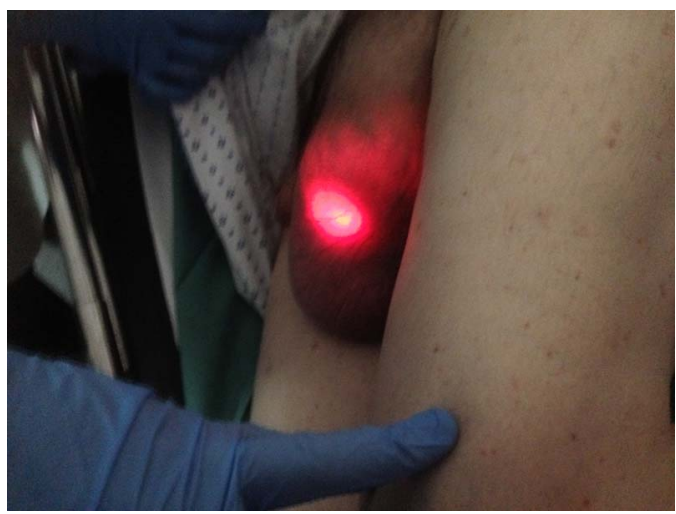

Figure 1 Transillumination of the scrotum from a colonoscope incarcerated in a left inguinal hernia. ing anatomical difficulties encountered during the performance of colonoscopy in patients with significant amounts of colon incarcerated within right or left inguinoscrotal hernias. ${ }^{1-3}$ We believe that this image captures a rare phenomenon, a unique variant of the transillumination test.

\section{Learning points}

Inguinoscrotal hernias may contain varying anatomical structures including omentum, small bowel or colon.

- Colonoscopy may rarely be impeded by the presence of a redundant colonic loop within an inguinoscrotal hernial sac, most frequently on the left side.

- Failure to advance the colonoscope in these circumstances is due to the anatomical configuration of the incarcerated colonic segment.

Contributors $\mathrm{Ml}$ performed the scope and wrote the manuscript. Literature review was by RW and JB. KB reviewed and approved the final version

Competing interests None.

Patient consent Obtained.

Provenance and peer review Not commissioned; externally pee reviewed.

\section{REFERENCES}

1 Tan VP, Lee YT, Poon JT. Incarceration of a colonoscope in an inguinal hernia: case report and literature review. World J Gastrointest Endosc 2013:5:304-7.

2 Lee YT, Hui AY. Failed colonoscopy due to hernia. Endoscopy 2004:36:758.

3 Fan CS, Soon MS. Colonoscope incarceration in an inguinal hernia. Endoscopy 2007;39(Suppl 1):E185.

\footnotetext{
Copyright 2014 BMJ Publishing Group. All rights reserved. For permission to reuse any of this content visit http://group.bmj.com/group/rights-licensing/permissions.

BMJ Case Report Fellows may re-use this article for personal use and teaching without any further permission.

Become a Fellow of BMJ Case Reports today and you can:

- Submit as many cases as you like

- Enjoy fast sympathetic peer review and rapid publication of accepted articles

- Access all the published articles

- Re-use any of the published material for personal use and teaching without further permission

For information on Institutional Fellowships contact consortiasales@bmjgroup.com

Visit casereports.bmj.com for more articles like this and to become a Fellow
} 